\title{
10 INDIVIDUAL AND COLLECTIVE RIGHTS IN AFRICA: DUAL WORLDS OF LAW, RELIGION AND AFRICAN TRADITIONAL HERITAGE
}

\section{Nokuzola Mndende ${ }^{1}$}

\section{INTRODUCTION}

At independence, the new African regimes run by native Africans surprisingly perpetrated the contempt imposed by Western systems on indigenous society. Instead of using the opportunity of independence to reinstate the supremacy of indigenous law over and above Western law and society, native African rulers became even more aggressive in suppressing their own civilization. ${ }^{2}$

As African states had been under colonial rule for a long time, it was a dream of most Africans that when their fellow Africans took the leadership in postcolonial era, Africans would be holistically free. It was very unfortunate that after a lot of blood was spilt fighting for the liberation of the oppressed, such leaders continued to perpetuate the very Western stereotypes that were entrenched in the foreign religions and the laws that were introduced in the respective countries. To cite one example, South Africa was incorrectly declared a Christian country, suppressing the indigenous spirituality and causing anyone who resisted Christian to be regarded as an atheist, pagan or heathen; hence African names were called heathen names. The indigenous law was suppressed and Roman-Dutch law took the centre stage. The restoration of the religion and the law of the land was supposed to be the first priority of the indigenous people after liberation. But the opposite happened - the leaders just became white souls in black skins. To date in South Africa, Christianity and Roman-Dutch law still take the centre stage - thus suppressing the indigenous law and spirituality.

As a result of the above, in any attempt to try to discuss an African perspective on many issues - for instance, individual rights in conjunction with collective rights within the sphere of African culture and spirituality - the debate always ends up reflecting the ongoing conflict between African culture and Western culture. African culture is, rightly or wrongly, perceived as specialising in collective rights; whereas Western culture is, rightly or wrongly, perceived as specialising in individual rights. Such perceptions always put each culture in a

1 Dr Nokuzola Mndende, Icamagu Institute, University of the Free State, South Africa.

2 Hansungule M. 2014. “Culture, Governance and African Human Rights in Critical Perspective", International Journal of Arts and Commerce 3(1):69-86. 
box, as the concept of "nuclear family" is associated with Western culture and the concept of extended family is associated with African culture.

Defining rights laid down by customs and rituals is a very complex exercise, as it cannot be defined in simplistic terms. This is due to the fact that, though individual rights do exist in the African communities and are also fundamental rights for all individuals, they are defined and applied in a manner that is dictated by the customary law of the land. Since the foundation of all customs and rituals is believed to be grounded in the concept of ubuntu, which dictates that whatever one is doing for the benefit of humanity, before taking any decision one must make sure that it is not going to affect others negatively, and the decision must benefit the surrounding community. In order to be reminded of the basis of $u b u n t u$, there are rules and regulations that are to be adhered to in all activities in the course of human life, and these are taught in daily activities by the elderly who, in turn, are believed to be "students" or "ambassadors" of the ancestors. These rules and regulations, as they focus on the collective and communal, may be unfair to some people at the individual level, especially those who occupy positions by birthright, because they have to comply with the dictates of the customs or traditions. Individual rights are accepted only if they have positive effects both for the individual, and also for the people and environment in which the individual resides.

In this chapter, I will discuss the understanding of individual rights as compared with collective rights in African traditional communities. The focus will be on the South African experience, specifically that of the Xhosa community, which is my lived experience. Though this is my point of departure, one will notice that there are many commonalities with other African countries. With respect to the context of South Africa, it will also be important to examine how such a multi-cultural and multi-religious country unequivocally blends together the application of both individual and collective rights, without marginalising or dictating to any group within its pluralistic country, as per the Constitution. One must understand that South Africa has accommodated many religions, such as African Traditional Religion (ATR), Buddhism, Baha'i, Christianity, Islam, Judaism and many more. With the presence of these religions, South Africa is a multi-cultural society, but all these cultures and religions must abide by one Constitution and one rule of law.

\section{LAW, RELIGION, AND CULTURE IN AFRICA}

The Constitution of the Republic of South Africa, 1996, ${ }^{3}$ is the supreme law of the land, drafted by lawmakers in Parliament and enacted through statutes. However, the Constitution's enactment has not always been received without controversy among South Africa's indigenous peoples. South African legal

3 Constitution of the Republic of South Africa, 1996. 
scholar Michelo Hansungule mourns the domination of Western culture in Africa's Constitution after independence, arguing that:

The perpetuation of alien law and systems in independent Africa has dealt a severe blow to the whole idea of independence in Africa. Constitution after constitution while proclaiming the importance of traditional African values nonetheless subordinated these values to Western values in the form of the bill of rights in fact nothing more than a simple act of "cutting and pasting" from the foreign documents to equally "foreign" but domesticated instruments. ${ }^{4}$

The South African Constitution has, for example, used civil marriage as a basis of the law of succession; yet the law of the land makes customary law the basis of a recognised marriage. In the traditional leadership of South Africa's indigenous cultures, succession is based on the status of the mother, if she is from a royal family and is married the indigenous way. Many Africans in indigenous communities have lost their rights because the recognised marriage is one from the magistrate's court irrespective of having no recognition by the family.

Another example is a pending high court case in Mpondoland area of Ngqeleni district in South Africa. The case involves a polygamous chief who passed on in 2015 and yet had not been buried as of this writing in April 2017. He left the main homestead and stayed with his junior wife, but the junior wife is refusing to release his body, claiming that it was his will that he must be buried in her homestead. According to custom, however, a chief must be buried in the main homestead where his father and grandfather were buried. There is now a dispute between the family and community, who believe that he must be buried at the main homestead, and his junior wife, who is claiming otherwise. He is still in the mortuary. The junior wife cited her individual rights at the high court, because she knew very well that the traditional court would favour the senior wife.

This is the problem of the limitations of the Bill of Rights in the South African Constitution. The Bill of Rights deals with individual rights and does not explain how these rights, if applied irresponsibly, could affect the rights of the people around. A critical analysis of some of the statutes relating to individual and collective rights in South Africa is important in order to assess whether they emphasise individual rights more than collective rights or vice versa, and whether they are applied in a balanced manner.

Most Africans now find themselves caught up in an environment where they experience an identity dilemma, because they are now living in pluralistic societies and have to adjust and represent themselves as progressive and modern. The government has passed many laws without advice and advocacy

4 Hansungule, "Culture, Governance and African Human Rights in Critical Perspective". 
from the communities. The Children's Act, for instance, focuses on the rights of the child only and is silent on the rights of the parent to raise a morally stable and responsible child. The parent will only be involved when the child commits a crime and is underage, in which case the child must be under the care of the parents. Another example is the Civil Union Act, 2006, which permits samesex marriage. This is cast as an individual right to be respected. But it creates problems where there is lack of sexuality education within the communities and when there is a clash with the set norms of their communities and their religions when they get married. In most African communities, marriage is solely for procreation, and the communities have set gender roles which exclude homosexual or intersex people. LGBT citizens feel that the Constitution covers them, but their home communities and many families violate their rights by denying them the right to marry freely. These circumstances have resulted in people living in two worlds: the rural world and the urban worlds. In the rural world, customary law still dictates, but in the urban or city world there is a blend of the two laws.

But living in two worlds has made some Africans feel like quasi-citizens in their own land, coerced into being voiceless and disenfranchised participants, as decisions are taken by members of parliament without the majority being given an opportunity to be active participants in the debates. Laws such as the legalisation of abortion, ${ }^{5}$ the Civil Union Act, ${ }^{6}$ and the Children's Act, ${ }^{7}$ to cite a few, were never discussed at the grass-roots level with people in their communities in their indigenous languages, but only in Parliament and city and town halls, which are areas that people could not afford to attend. What made things worse was that even in those town halls, the medium of instruction used was always English, which is not the mother tongue of the local people. This was done despite awareness that the majority of the people are not in the cities, but in rural areas where indigenous languages are used. One must not think that I am advocating for the abolition of these laws. Rather, what I am saying is that the discussions were and are still one-sided, and as a result the rural people and indigenous people are still on the receiving end of injustice. Most of the time, they hear it first from the media of the laws that are passed in Parliament, and it is complete news to them.

Everyday Africans in their ancestral land are made to live in two worlds. At home they live a communal way of life, which is foundational and not a choice, but rather dictated by tradition to all members of the community. At work, they inhabit another world in which Western-style individualism is central and imposed by the Constitution and law. Though it is true that culture evolves, it is also clear that culture on its own is not a single-layered entity, but instead made up of three layers, which can be considered as clothes or skins shed with different degrees of difficulty.

5 Choice on Termination of Pregnancy Act, 1996 (Act No. 92 of 1996).

6 Civil Union Act of 2006 (Act No. 17 of 2006).

7 Children's Act (Act No. 38 of 2005). 
The first layer is a superficial culture, which is easy to adjust and unclothe, including such matters as housing, transport, cosmetics and many other public dimensions of life. The middle culture is difficult to shed unless one compromises one's identity by renouncing practices, such as individual naming, religious affiliation and language, just to name a few. The deep culture, which cannot be shed or peeled off includes one's race, roots, identity and ethics. In nearly all indigenous African societies, these are based on the communal way of life; hence it is rare to find an African being individualistic instead of acting as a representative of his other family and broader community. For example, in the African way of life, it is regarded as foreign when an individual concentrates on the "nuclear family" consisting of only the father, mother and biological children.

When it comes to matters of freedom of religion and belief, Africans also have a different perspective. In African culture and spirituality, no one is converted into a way of life, but they are born into an already existing tradition. People do not apply to belong to it or decide to abandon it. Even if one chooses to ignore tradition, it is believed that there are ways to remind the individual of their roots, either through physical sickness or escalation of behavioural imbalances. Even those Africans in diaspora have ways of showing their nostalgia by creating new forms of acting out the communal way of life.

The complexity of defining an individual as separate from the surrounding community can also be seen in his life journey of his participation in social and spiritual activities. In a religious and spiritual sense, it is believed that life is a journey from conception to the life hereafter - that is, the world of ancestors. No individual lives alone, but rather among other people, hence the Xhosa saying "umntu ngumntu ngabantu" (a person exists amongst other people and his or her wellbeing depends on other people). Through all of the stages of life, including birth, initiation, marriage and death, rituals expressing the communal and social aspect of human life are performed by and for individuals, with clan and community as witnesses.

One could wonder why African traditional communities always link the individual rights and those of the collective. The answer is simple: it is based on the relationship between the individual and the ancestors. The two cannot be separated, as they are believed to constitute what is called a family. In African tradition, the interaction between individual rights and those of the collective begins at birth of each individual. The rites of passage, which are the rituals of birth, puberty, marriage and death, for example, reflect this sense of spiritual collectivity. A newborn baby is formally incorporated into the community of the living and the departed when the inkaba (umbilical cord) is buried at the ancestral home by the elderly. The place where the inkaba and the ancestors are buried is referred to as one's "home" - that is, one's roots. Home, in this particular case, does not only refer to the infrastructure, but also refers to the ancestral land. The incorporation of an individual into the wider community is 
also a process that is done after death, with many communities performing the mourning rituals for the deceased relatives.

African philosopher and theologian John Mbiti clearly shows how an individual is made to be part of the whole in the rituals of the African spiritual world. In this regard, Mbiti observes:

We have seen that birth is the first rhythm of a new generation, and the rites of birth are performed in order to make the child a corporate and social being. Initiation rites continue that process, and make him a mature, responsible and active member of the society. Marriage makes him a creative and reproductive being, linking him with both the departed and the generations to come. Finally comes death. Death stands between the world of human beings and the world of the spirits, between the visible and the invisible. ${ }^{8}$

In all these stages, there are teachings, taboos and responsibilities dictated by traditions and customs for a peaceful society. There are admonitions, advice, and emphasis on sharing and feelings of empathy toward the person next to you in the rites of passage and one's behavior in daily life in relation to age groups. All of these rituals and social practices make it very difficult to isolate individual rights from collective rights, as they are always intertwined.

\section{THE SOCIAL WORLD OF AFRICAN RIGHTS}

\section{Clan and kinship}

As many African-societies are clan-based, and the clan is what identifies an individual, no individual leaves in isolation of their clan. Clan names are derived from the names of the leading ancestors who, because of their birth rights, were either chiefs or heads of their respective clans. These, together with other deceased members of the family, are believed to be in spiritual communication with the living. In the process of self-definition, an individual is expected to recognise that he or she is a product of basically four clan names which are the paternal (father), maternal (mother), maternal grandmother and paternal grandmother. It is believed that the genes of these clans are in each individual's blood; hence he or she shares the joys, burdens and sorrows with them and calls them family members. Another typical example of an individual living within a collective is the way of greeting another person. This involves inquiries into the health and wellbeing of the individual, but also his or her relatives and environment.

8 Mbiti JS. 1969. African Religions and Philosophy. London: Heinemann, 149. 


\section{Greetings}

Though I am not going to deal comprehensively with all of the nuances of African language in this chapter, the language of greetings is a key example of how collective rights often supersede individual rights in African culture. When two individuals greet each other, the responses from each always reflect the collective. Any individual who responds in an individualistic manner, such as, "I am fine", to the question of how they are doing, is labelled as an urban or city person, or as a Westerner or a white person. A typical African response is always inclusive of others; hence it takes a longer time to finish. A typical example below is cited between Person A and Person B. One must also observe that this is a two-way communication in which one must confirm that he or she understands or is listening. As these specific speakers are using isiXhosa (one of the indigenous languages) "Ewe" (yes) is constantly used as an affirmation or is uttered through the nose with a closed mouth as "Mh" or as "Mh-mh". These responses are just a common communication between two people and not based on gender or age or status. It is an individual explaining the situation within the self and of those in the surrounding community.

\begin{tabular}{|l|l|}
\hline PERSON A & PERSON B \\
\hline $\begin{array}{l}\text { Ninjani? } \\
\text { (How are you [plural]?) }\end{array}$ & $\begin{array}{l}\text { Siphilile. } \\
\text { (We are fine.) }\end{array}$ \\
\hline $\begin{array}{l}\text { Ewe/Mh. } \\
\text { (Yes.) }\end{array}$ & $\begin{array}{l}\text { Namahlaba sihamba nawo. } \\
\text { (We are going forward with our body aches.) }\end{array}$ \\
\hline $\begin{array}{l}\text { Ewe/Mh. } \\
\text { (Yes.) }\end{array}$ & $\begin{array}{l}\text { Nasekhaya ndishiye kungekho nto. } \\
\text { (Even at home they were fine when I left.) }\end{array}$ \\
\hline $\begin{array}{l}\text { Ewe/Mh. } \\
\text { (Yes.) }\end{array}$ & $\begin{array}{l}\text { Ngaphandle kukamama osoloko enkenenkene. } \\
\text { (Except my mother who is always weak.) }\end{array}$ \\
\hline $\begin{array}{l}\text { Ewe/Mh. } \\
\text { (Yes.) }\end{array}$ & $\begin{array}{l}\text { Nembalela isiphethe kakubi. } \\
\text { (This drought is killing us.) }\end{array}$ \\
\hline $\begin{array}{l}\text { Ewe/Mh. } \\
\text { (Yes.) }\end{array}$ & $\begin{array}{l}\text { Imfuyo iyafa. } \\
\text { (The livestock is dying.) }\end{array}$ \\
\hline $\begin{array}{l}\text { Ewe/Mh. } \\
\text { (Yes.) }\end{array}$ & $\begin{array}{l}\text { Ninjani nina? } \\
\text { (How are you?) }\end{array}$ \\
\hline $\begin{array}{l}\text { Hayi Nathi siphilile. } \\
\text { (We are also fine.) }\end{array}$ & $\begin{array}{l}\text { Ewe/Mh. } \\
\text { (Yes.) }\end{array}$ \\
\hline
\end{tabular}

In this exchange, Person B will also reflect not only his/her own personal health, but also that of his/her family and the environment.

\section{Blood and marriage relations}

To be related by blood ukuzalana (blood) is very important in African culture. In the central rituals of African culture, participation is exercised not only at the level of the relationship by paternal side only, but also by the maternal side; 
hence, the umtshana (nephew/niece) has a special role in her/his maternal side. In Xhosa culture, the term umtshana is a neutral term referring to "one's sister's child". My sister's child (boy or girl) is my mtshana, but my brother's child is my child, since we are of the same blood and hence we share the same clan names. This again, explains how an individual should always be in connection with those around him/her before thinking about personal rights.

Through marriage, another level of relationship is that of the parents of the married couple, who are also united by the marriage ritual. These parents call each other mkhozi and share joys, sorrows and burdens together. The term $m k h o z i$ "not only refers to parents links to their biological children, but also to the parents of their child's spouse" The parent of my brother's daughter-in-law for instance is my mkhozi though my brother's son has his own parents, but the fact that my brother's son is a Mndende, makes him my son, too.

In this context, no individual lives in what is called a "nuclear family". An individual is a product of at least four families, the one of the father (paternal and maternal), and that of the mother (both maternal and paternal). The individual must understand that he or she is the product of at least four ancestries, including those of the mother, father, maternal grandmother and paternal grandmother. By this knowledge, an individual is related to these families. No individual in African culture could claim monopoly of one parent family line or count as siblings only those born from the same biological parents. In the example below, the children of the three brothers cited below all call the brothers their fathers and the difference is the time each was born. Each of the fathers is considered as what would be referred to as "uncle" in English.

\begin{tabular}{|l|l|}
\hline BROTHER & TITLE \\
\hline Xuza & Tata omdala (eldest father) \\
\hline Mzimkhulu & Tata ophakathi (middle father) \\
\hline Wele & Tata omncinci (young Father) \\
\hline
\end{tabular}

The above table shows what the children of the three brothers call their "fathers". Those of Xuza for instance call him Tata, but call Mzimkhulu Tata ophakathi, and call Wele Tata omncinci. All of the children of these brothers regard themselves as siblings. Moreover, to be a sibling does not only extend to the families of these "biological" brothers, but goes beyond to all those who share the same surname and clan names.

These types of relationships amongst community members are clearly described by Mbiti, who observes of this notion of family or kinship through blood and betrothal, "It is kinship which controls social relationships between people in a given community, it governs marital customs and regulations, it determines the behaviors of one individual towards another." ${ }^{\prime \prime}$ The scope of kinship does

9 Mbiti, African Religions and Philosophy, 104. 
not only extend to the relationship between relatives by blood and marriage, but goes beyond and involves the vertical aspect of the relationship. It goes to those who have departed, - that is, the ancestors as a collective (matriarchal and patriarchal) whose influence is highly respected in the lives of the living. Ancestors are the point of departure in all activities of the living and the environment and they are believed to be intermediaries between the living and the Creator. As Mbiti describes it:

The kinship system also extends vertically to include the departed and those yet to be born. It is part of traditional education for children in many African societies to learn the genealogies of their descent. The genealogy gives a sense of depth, historical belongingness, a feeling of deep rootedness and a sense of sacred obligation to extend the genealogical line. ${ }^{10}$

What Mbiti explains above clearly indicates that an individual is an entity that is defined from a very broader perspective both horizontal (living clan members) and vertical (those who have departed which are ancestors). This clearly indicates that an individual is an ambassador who must be careful that his/her action are a reflection of not only his/her but his family of the living and the departed. This means that $\mathrm{s} /$ he may fall in love with a specific action but if the act is against his family, that means s/he must abstain from it though s/he thinks it falls within his/her rights.

\section{Firstborn children}

As there are different levels in the social structure in African communities, there are also different duties and responsibilities which an individual does not perform only for himself or herself, but also for the broader community. These are the natural duties dictated to those who are born within certain levels in the family or community. Among the amaXhosa for example, the firstborn male is not allowed to build his own homestead. He must remain at the communal home, as he will be expected to take over the responsibilities of his father when he passes on. A firstborn male in my community has to be the representative of their father, therefore his rights are dictated by tradition. His wife, too, must know the expectations and limitations of marrying a firstborn male, hence she must also be from a royal family. The wife of a firstborn male knows that she is to also take the responsibilities of the mother in law, she is going to be practically the "mother" to all the children of her husband's younger brothers and sisters. She has to help in solving some problems of her husband's paternal aunts.

One may ask what happens if the firstborn is a girl? The answers is that even if a firstborn male means is born after girls, he is still a firstborn male. Because the Xhosa are a patriarchal society, it is assumed that girls will marry and leave home, so the firstborn male will be the one to remain at home. All his siblings are

10 Mbiti, African Religions and Philosophy, 105. 
free to go and establish themselves elsewhere, but come back to perform rituals at their communal home, when the need arises. In an ideal situation, if one of his sisters separates from her husband and comes back home, the firstborn male (her brother) should take responsibility of her and her children. The firstborn woman's umafungwashe (responsibilities) are mostly spiritual to her brothers' children. Even if she is married, during ritual activities she is obliged to come back home to perform her responsibilities. She will only go back home after the ritual has been finished.

If one of the brothers of the firstborn male passes on at an early age and leaves behind small children, it is the responsibility of the firstborn male to provide for his brother's children as they are also regarded as his responsibility. This may involve either be taking responsibility of all of them or discussing with extended family members how to share this responsibility. This when close relatives may decide to $u k u$ thatha (take responsibility or adopt) each depending on the agreement with the clan members. This would be what the west calls adoption. Taking on the responsibilities of the father does not, however, entitle the first born to expropriate the intestate to his or her personal use, as happens in some modern societies where, upon the intestate death of a relative, family members descend like greedy vultures onto his or her property without any thought to surviving children or spouse.

The question that needs to be asked is how far does the right to freedom of religion for instance go when an individual occupies a position in traditional leadership whose duties are prescribed by his birth right and not by his personal rights? In fact, in many parts of Africa, a firstborn son has both religious and cultural duties and is, in fact, a sacred person since he leads all the religious activities in his family. Customary law scholar, TW Bennett explains the customary law of succession in African societies as follows:

The African system of succession is invariably patrilineal. The rules of succession to a deceased are the same for all systems of customary law in South Africa. The guiding principle is always primogeniture in the male line. The ideal candidate for heir is therefore the deceased's eldest son or, failing him the eldest son's eldest male descendant, namely, the eldest surviving grandson. Failing any male issue in the eldest son's line, succession passes to the second son and his male descendants, and so on, through all the deceased's sons. ${ }^{11}$

Customary law scholar Alastair James Kerr agrees with Bennett, stating:

If the deceased had no descendants the whole range of male ascendants are considered in order of "seniority". It is governed by the principle of primogeniture that even in polygamous marriages prevails. The rules are plain, straightforward and part and parcel of their system of family

11 Bennett TW. 2004. Customary Law in Southern Africa. Cape Town: Juta \& Co, 337. 
law, catering among others for the status and wellbeing of all members of an extended family. ${ }^{12}$

What Bennett and Kerr show above is that those who are born within the royal families (chiefs and kings) find themselves in a difficult situation when it comes to individual rights, when they have a right to adopt the religion of their choice for instance, but when it comes to their birth rights, they also have to comply with the rights of the people they lead without denouncing those cultural rights. As a chief is not chosen but born, he is bound by the customary law which is based in African Traditional Religion (ATR), this situation makes the chief to be ATR at home and Christian outside home.

\section{INDIVIDUAL RIGHTS, COLLECTIVE RIGHTS AND HUMAN RIGHTS.}

The question that needs to be raised from this examination of individual and collective rights in African cultures in the global human rights context is the sphere within which we should begin to talk about nature of human rights. Should we first think locally then globally or vice versa? If we talk of global human rights, how do we define global when the globe is made up of countries in which are localities that are also part of the global village? Talking about international human rights without considering the heritage of the people concerned is also a violation of their human rights. Multiculturalism should be recognised, as culture defines the identity of the people. What is needed is a dialogue on the commonalities and cultures.

An individual is a complex entity whose blood is a product of different clans. The individual is an ambassador of those clans and communities, since the concept of a "nuclear family" does not exist in Africa. Even an evolving culture cannot erase the practice of a collective, as even in cities Africans are practising their cultures adapting them into their new environment. In most cases, an individual is identified not by his personal name, but by those close to him by blood or by the clan.

Individual rights are never isolated from collective rights. In fact individual rights are dictated by collective rights. That is why even those Africans who decide to convert to other religions besides their indigenous one, either choose to isolate themselves from their roots, which is a very difficult situation as they are neither here nor there, or they choose to be syncretic, that is, practising both worldviews. If they accept syncretism, then at home they are African, but outside the home, for various reasons, they live in two worlds - the indigenous world to satisfy spiritual and cultural interests and the corporate world in order to satisfy economic needs. An individual is moulded by family, kinship and clan, using the culture and spirituality of that specific group based on the prescriptions from the spiritual world. Deviation from prescriptions is believed

12 Kerr AJ. 1990. The Customary Law of Immovable Property and Succession. Third Edition. Grahamstown: Grocott \& Sherry, 99. 
to anger the Creator and ancestors. Leaders are expected to lead by example and to take on from what their ancestors left. As there are different levels of leadership, there are also different expectations regarding rights and freedoms.

Multiculturalism and democracy have led to people to make choices that fulfil their internal interests. The interaction of African customary law with the new legal systems that came with evolving history has also opened up a scope to learn about human rights of other nations of the world. Though the insiders in any culture see their ways as supreme, there are sometimes areas where one fills coerced to follow a certain path in fear of the collective even if that path violates some personal beliefs. The issue of patriarchy and gender stereotyping for instance has caused some modern women to be labelled in very negative terms. Now that women are part of the corporate world and political hierarchies, they are no longer expected to be confined to their houses where gender roles are expected to be followed.

The other challenge is the limited scope of an individual to choose not to follow traditional customs and to adopt new beliefs. An example of a young man in the area of Ciskei in the Eastern Cape province of South Africa who did not want to undergo the traditional male initiation as a puberty rite is one to be cited. In African culture this rite is compulsory, as it is believed it's a transition from boyhood to adulthood, and the young man was forced by his father to undergo it. When he came back from this rite, which was against his beliefs, he took his father to court and won the case - yet he was labelled in many ways as an outcast. On the other hand, South Africa is now experiencing an increase in the number of white boys who decide to undergo this rite an African way, and they are allowed to do so as long as their parents agree. This indicates that in a balanced society it is difficult to separate the individual rights from the collective. Each one must listen to the other and sometimes, for the sake of peace, a compromise must be reached.

\section{CONCLUSION}

To sum it up, it is important to highlight that though there is a recognition of individual rights in modern African societies, they must not threaten or undermine the rights of other people who may be affected. The question is how far can an individual compromise personal rights because of the obligation to satisfy the collective rights? Also, it becomes more complex if there is no interest in balancing up the rights and a changing society. Now that societies are expanding from local to global in their perspective, there is a need to consolidate the rights of the community as a foundation - embracing those that promote morality and unity, excluding those that are discriminatory, and making peace within and among communities.

Ultimately, individual rights must make others comfortable, too. Rights must be accompanied by responsibility, compromise for the sake of others and an ethical 


\section{RELIGIOUS PLURALISM, HERITAGE AND SOCIAL DEVELOPMENT IN AFRICA}

concern to have positive output for all. This approach is consistent with ubuntu - the African heritage of collective concern for others, aimed at developing the whole society. 